\title{
Research International Journal of Chemistry and Analytical, Bioanalytical Chemistry
}

Research Article

\section{Assay of the Molecular Compositions of Different Clay Types based on Industrial Applications}

\author{
Suresh Aluvihara*, C.S. Kalpage \\ Department of Chemical and Process Engineering, University of Peradeniya, Peradeniya, Sri Lanka
}

*Address for Correspondence: Suresh Aluvihara, Department of Chemical and Process Engineering, University of Peradeniya, Peradeniya, Sri Lanka. E mail: sureshaluvihare@gmail.com

Received: 05 June 2020; Accepted: 09 July 2020; Published: 11 July 2020

Citation of this article: Aluvihara S, Kalpage CS (2020) Assay of the Molecular Compositions of Different Clay types based on Industrial Applications. Rea Int J of Che and Ana I and Bio Chem. 1(1): 001-004. DOI: 10.37179/rijcabc.000001.

Copyright: (C) 2020 Aluvihara S, et al. This is an open access article distributed under the Creative Commons Attribution License, which permits unrestricted use, distribution, and reproduction in any medium, provided the original work is properly cited.

\begin{abstract}
The chemical composition of clay is a descriptive parameter regarding the selection of their advanced chemical properties such as the adsorption because different types of clays are having different characteristics because of the composed elements and some specific minerals and some of specific characteristics find the solutions for the urgent matters such as the control of environmental pollutions.

The analysis of the inorganic functional groups and the mineralogy of three of selected different clay types were the objectives of the existing research. The representative clay samples of three different clay types were analyzed using Fourier Transforms Infrared (FT-IR) Spectrometer.

The results disclosed that those clays were composed with kaolinite, quartz and muscovite as the minerals regarding each of clay. When considering the chemical properties of kaolinite, it has been realized as a strong absorber for some of metals such as $\mathrm{Co}, \mathrm{Cd}, \mathrm{Ni}, \mathrm{Mn}, \mathrm{Ni}$ and some pathogens. Therefore these clay varieties may have a wide range of applications in the water treatments applications regarding the different waste water types which are having various chemical compositions and pollutants.
\end{abstract}

Keywords: Clay, Functional Groups, Organic and inorganic molecules, Infrared spectroscopy, Chemical composition

\section{Introduction}

Clay is an industrially applicable natural resource because of the vastly found some physical and chemical qualities of such clay. In the ancient world, the industries based on clays had been limited for a few of tasks as follows [1-6].

- $\quad$ Building materials

- Pottery industries

- Fancy items

But according to the requirements and environmental issue of the society, the usage of clay is increasing via different orientations such as the water treatment applications, ceramics and porcelains, catalytic activities and ion exchanging materials including as a single material or composite material.
When comparing of the chemical compositions of clays, it is known as a group of clay minerals such as montmorillonite, kaolinite and some other ferrous minerals including metal oxides. When considering the structures of clays, they were identified as some complex structures because of the presence of complex silicate structures $[1-4,6,7]$.

Adsorption process is much considerable parameter regarding the advanced chemical applications of water treatments and the kaolinite, montmorillonite and some of other ferrous minerals play a huge role in the water purification processes.

According to the definitions of the adsorption two major components have been defined namely as adsorbate and adsorber. The adsorption capacity of an adsorber may be varied with the type of 
adsorber and type of adsorbate because of the strength of electrostatic forces which are acting between both adsorbate and adsorber. The categorization could be done as follows with the examples [3-8].

- Adsorber - Clay, composite minerals

- Adsorbate - Heavy metals, organic matter, inorganic matter, radioactive elements.

The applicability of different clay varieties on the different industrial purposes have been investigated through the most of modern research and the development of some new clay types and disclosing of the important characteristics of such clays create some new approaches for most of science and engineering stuffs.

In addition that there were found a series of different industrial uses of clay because of the presence of some specific components in clays such as the metallic ions, $\mathrm{Fe}$ minerals, $\mathrm{CaO}$ and so on. Based on the recent researches following advanced characteristics were investigated in different clay verities in the world [8-14]

- Ion exchanging material

\section{- $\quad$ Refractory material}

In the existing research there were expected to characterize three different selected clay types based on the analysis of their organic and inorganic functional groups and also to make some review on their applications in advanced technological purposes.

\section{Materials and Experiments}

According to the scopes and objectives of the existing research, three different clay species were selected for the investigations and the representative samples of such clays were collected from the available locations in Sri Lanka as shown in the (Figure 1).

In the collections of the representative clay samples from the relevant locations, following precautions were practiced based on the mitigation measures of the experimental errors.

- Using of non-contaminated collecting tools

- Using of nonmetallic tools

- Storing of collected clay samples in polythene bags

- Avoiding of the exposure of clay samples to the direct sunlight because it is possible happen the evaporation of water/moisture also with some composed elements in clay or decay of some elements.

The selected clay types were labeled under the names which were based on their existing uses as described in the below.

- Anthill clay- Found from an anthill which was built by a termites (Matale area)

- Brick clay- Using in the manufacturing of bricks (Maduragoda area)

- Roof tile clay- Using in the manufacturing of roof tiles (Dankotuwa area).

The representative portions of the collected clay samples are shown in the (Figure 2).

Some sufficient clay portion from each clay type was demerged from each clay bulk. Each clay portion was oven dried for 24 hours under the temperature of $110^{\circ} \mathrm{C}$. The dried clay samples were

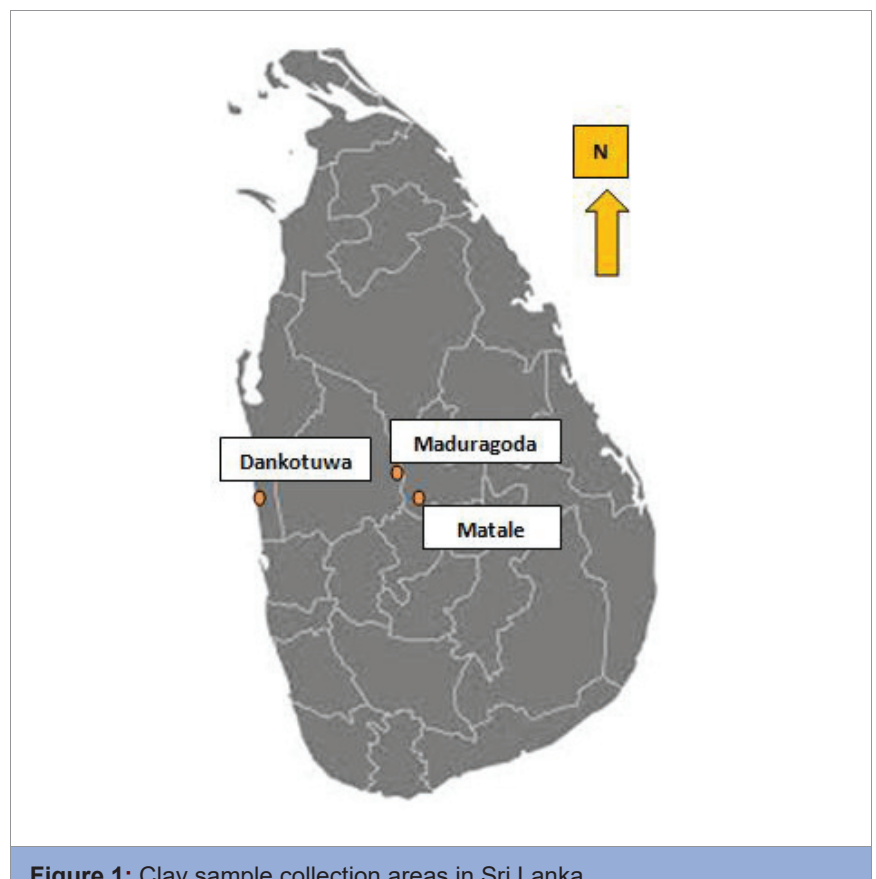

Figure 1: Clay sample collection areas in Sri Lanka.

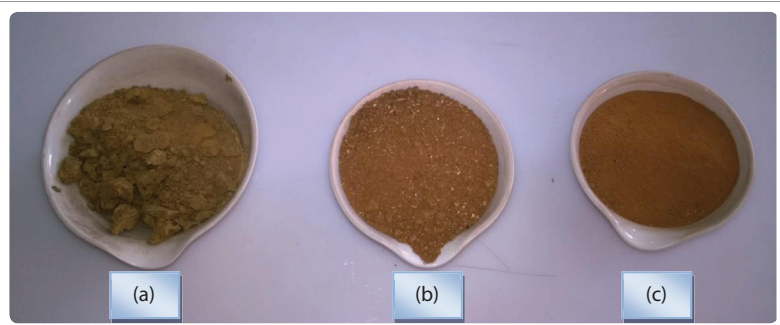

Figure 2: (a) Roof tile clay, (b) brick clay and (c) anthill clay.

separately dissolved in large measuring cylinders using distilled water while shaking the systems for a few of minutes.

The well shaken clay solutions were countenanced to settle down about three hours. Meanwhile the mutations of the systems were observed. The upper portion of the settled clay particles in each measuring cylinder was sucked and collected using a medical dropper. The upper parts of the measuring cylinders were consisted with tiniest clay particles of each clay sample.

The collected upper portions were oven dried for 24 hours under the temperature of $110^{\circ} \mathrm{C}$. The dried clay samples were crushed using a ceramic crucible and finer powdered clay portions were prepared from each clay type $[1-3,5,6]$. In the selection of final representative clay sample from each clay type, the coning and quartering method was adhered as shown in the (Figure 3).

This is well recognized method for the selection of some representative sample from a large portion of solid material in even handed. According to the definitions of such method, the final representative sample should be either the integration of quarter $A$ and quarter $\mathrm{C}$ or quarter $\mathrm{B}$ and quarter $\mathrm{D}$.

Eventually the selected representative clay samples were analyzed using a Fourier transforms infrared (FT-IR) spectrometer. The instrument is shown in the (Figure 4). 
Citation: Aluvihara S (2020) Assay of the Molecular Compositions of Different Clay Types based on Industrial Applications. Rea Int J of Che and Ana I and Bio Chem. 1(1): 001-004. DOI: 10.37179/rijcabc.000001.

According to the obtained results for the Fourier transforms infrared (FT-IR) analysis, the chemical compositions of the relevant clays were confirmed and their three dimensional (3D) structures were constructed using advanced computational chemical software while interpreting their important characteristics such as the bond lengths and bond angles.

\section{Results and Discussion}

The Fourier transforms infrared (FT-IR) spectrums of three different types of clays are shown in the following figures.

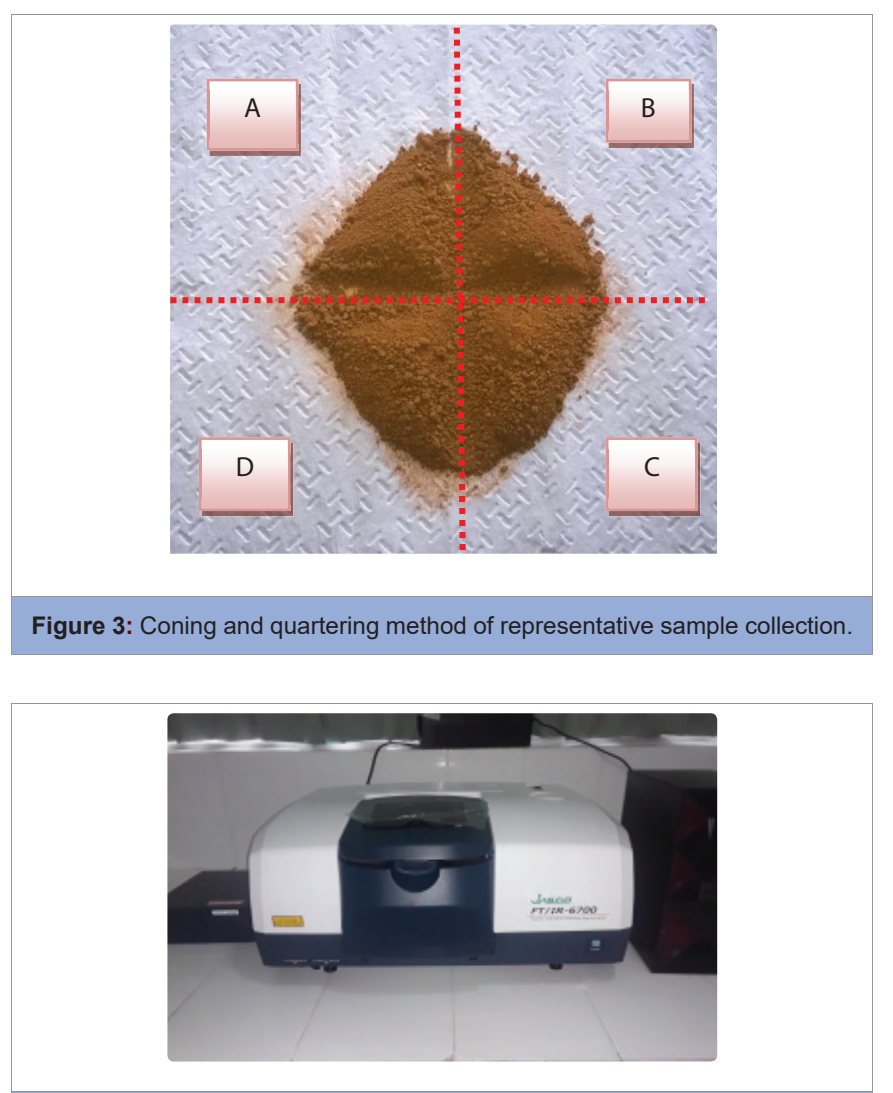

Figure 4: Fourier Transform Infrared (FT-IR) Spectrometer.

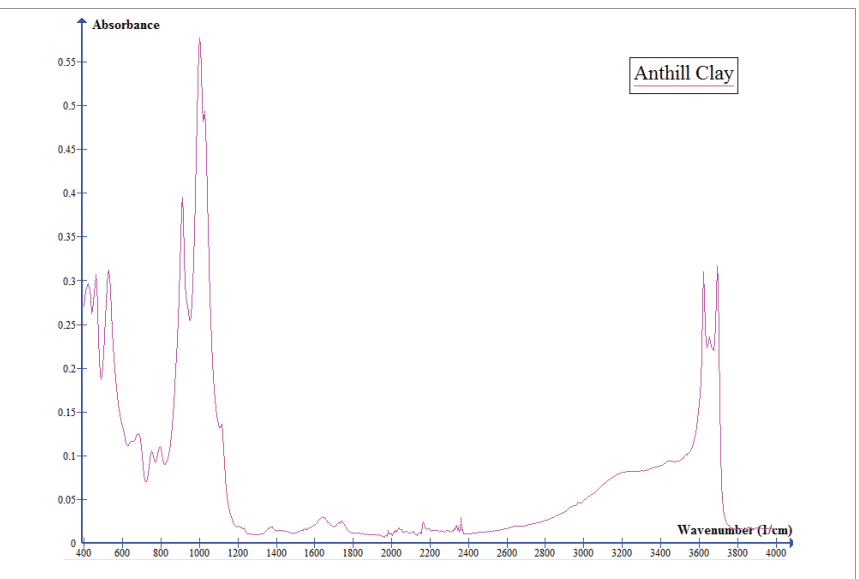

Figure 5: Fourier Transform Infrared (FT-IR) Spectroscopy of anthill clay (absorbance).
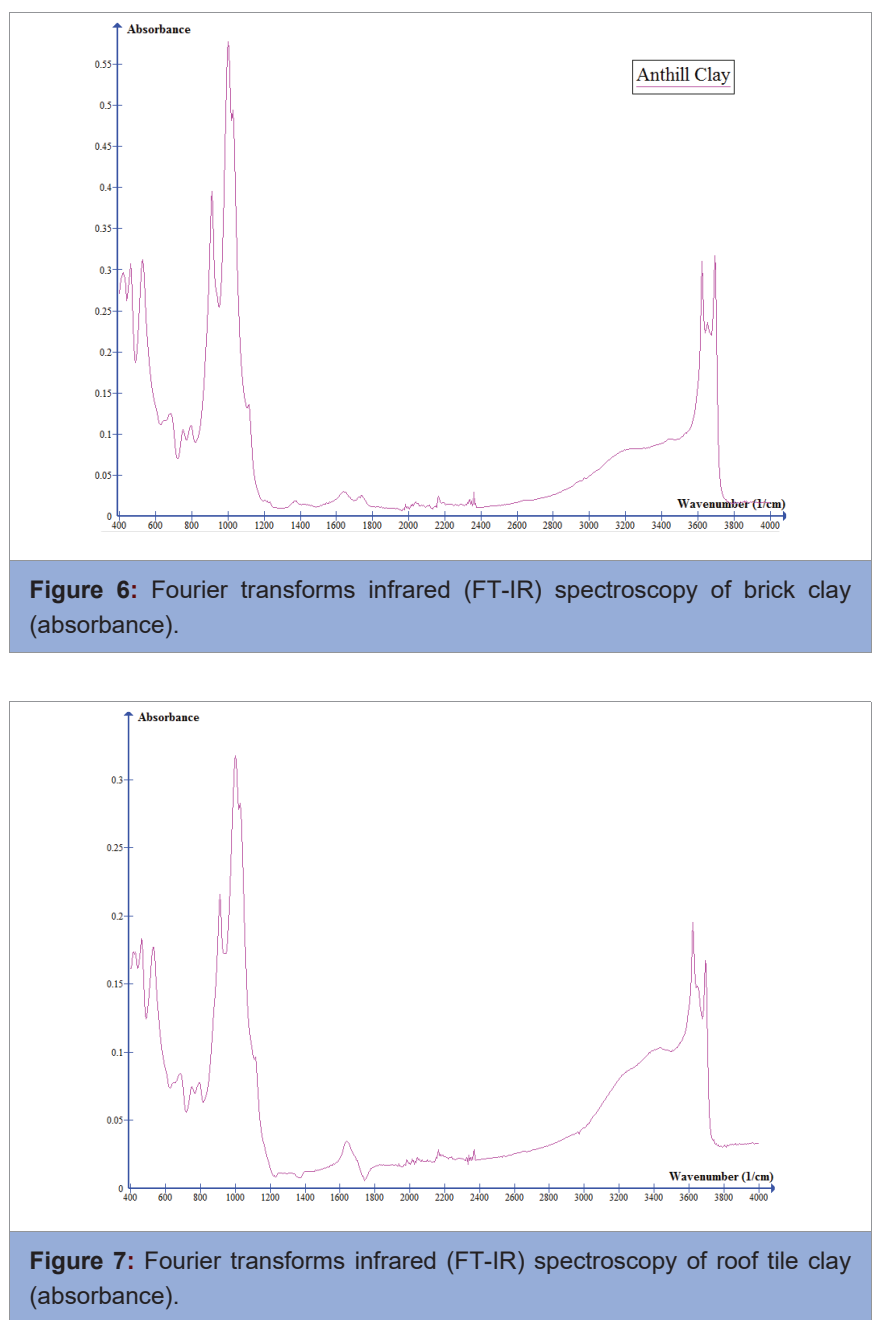

The highlighted main peaks of the FT- IR spectrums of anthill clay are described in the (Table 1) [1-4,8].

When considering the peaks at above wave numbers, it is possible to identify the presence of kaolinite in anthill clay as a clay mineral because of the identifications of the bonds of $\mathrm{OH}$ stretching of inner surface hydroxyl groups, $\mathrm{OH}$ stretching of structural hydroxyl groups, $\mathrm{OH}$ deformations of inner hydroxyl groups, Al-O-Si deformations and Si-O-Si deformations at the relevant wave numbers [3-5 14].

The chemical structures of kaolinite with bond lengths and bond angles are shown in Scheme 1 and Scheme 2. In addition that the peak at $999 \mathrm{~cm}^{-1}$ indicates the presence of muscovite and the peaks at $460 \mathrm{~cm}^{-1}$ indicates the presence of quartz $[1-5,9,10]$.

The highlighted main peaks of the FT- IR spectrums of brick clay are described in the (Table 2) [1-3, 5, 7].

The peaks at $3702 \mathrm{~cm}^{-1}, 3629 \mathrm{~cm}^{-1}, 1001 \mathrm{~cm}^{-1}, 909 \mathrm{~cm}^{-1}, 530 \mathrm{~cm}$ ${ }^{1}, 469 \mathrm{~cm}^{-1}$ indicates the presence of $\mathrm{OH}$ stretching of inner surface hydroxyl groups, $\mathrm{OH}$ stretching of structural hydroxyl groups, $\mathrm{OH}$ deformations of inner hydroxyl groups, Al-O-Si deformations and $\mathrm{Si}$ O-Si deformations $[3,5,14]$.

Therefore, the results confirmed the contents of kaolinite, muscovite and quartz in brick clay $[1,3,4,5,7]$.

The highlighted main peaks of the FT- IR spectrums of roof tile clay are described in the (Table 3) [1-4, 6, 7]. 
Citation: Aluvihara S (2020) Assay of the Molecular Compositions of Different Clay Types based on Industrial Applications. Rea Int J of Che and Ana I and Bio Chem. 1(1): 001-004. DOI: 10.37179/rijcabc.000001.

The FT-IR spectrum of roof tile clay showed the peaks at $3696 \mathrm{~cm}^{-}$ ${ }^{1}, 3623 \mathrm{~cm}^{-1}, 1001 \mathrm{~cm}^{-1}, 915 \mathrm{~cm}^{-1}, 530 \mathrm{~cm}^{-1}$ and $463 \mathrm{~cm}^{-1}$ that indicate the presence of $\mathrm{OH}$ stretching of inner surface hydroxyl groups, $\mathrm{OH}$ stretching of structural hydroxyl groups, $\mathrm{OH}$ deformations of inner hydroxyl groups, Al-O-Si deformations and $\mathrm{Si}-\mathrm{O}-\mathrm{Si}$ deformations $[2,3,4,14]$.

Therefore, the mineralogy of roof tile clay is much similar with other two types of clays [1-3, 5-7]

The mineral kaolinite has been identified as a strong adsorber because of the presence of hydroxyl groups and other electrostatic forces of bound atoms and the surfaces of such clays provide some platform for the process called the adsorption.

The adsorption process is quite useful in the water treatment applications such as the removal of heavy metals, removal of radioactive elements, removal of some inorganic pollutants and some pathogens. Also the physical property porosity is an important factor for the applications based on the key process of adsorption because of the increasing of the surface area due to the increasing of porosity $[1,3,4,7-10]$.

The three dimensional structures of kaolinite, muscovite and quartz with their bond lengths and bond angles are shown in following schemes.

Table 1: Assignments of the main peaks of FT- IR spectrum of anthill clay.

\begin{tabular}{|c|c|}
\hline Wave Number $\left(\mathrm{cm}^{-1}\right)$ & \begin{tabular}{c} 
Indicated Functional Group/Compound \\
\hline 3695
\end{tabular} \\
\hline 3628 & OH stretching of inner surface hydroxyl groups \\
\hline 999 & OH stretching of structural hydroxyl groups \\
\hline 910 & Si-O stretching \\
\hline 527 & OH deformations of inner hydroxyl groups \\
\hline 460 & Al-O-Si deformation \\
\hline 411 & Si-O-Si deformation \\
\hline
\end{tabular}

Table 2: Assignments of the main peaks of FT- IR spectrum of brick clay.

\begin{tabular}{|c|c|}
\hline Wave Number $\left(\mathrm{cm}^{-1}\right)$ & \begin{tabular}{c} 
Indicated Functional Group/Compound \\
\hline 3702
\end{tabular} \\
\hline 3629 & OH stretching of inner surface hydroxyl groups \\
\hline 1001 & OH stretching of structural hydroxyl groups \\
\hline 909 & Si-O stretching \\
\hline 530 & OH deformations of inner hydroxyl groups \\
\hline 469 & Al-O-Si deformation \\
\hline 420 & Si-O-Si deformation \\
\hline
\end{tabular}

Table 3: Assignments of the main peaks of FT- IR spectrum of roof tile clay.

\begin{tabular}{|c|c|}
\hline Wave Number $\left(\mathrm{cm}^{-1}\right)$ & $\begin{array}{c}\text { Indicated Functional Group/Compound } \\
\text { OH stretching of inner surface hydroxyl groups }\end{array}$ \\
\hline 3696 & OH stretching of structural hydroxyl groups \\
\hline 1001 & Si-O stretching \\
\hline 915 & OH deformations of inner hydroxyl groups \\
\hline 530 & Al-O-Si deformation \\
\hline 463 & Si-O-Si deformation \\
\hline
\end{tabular}

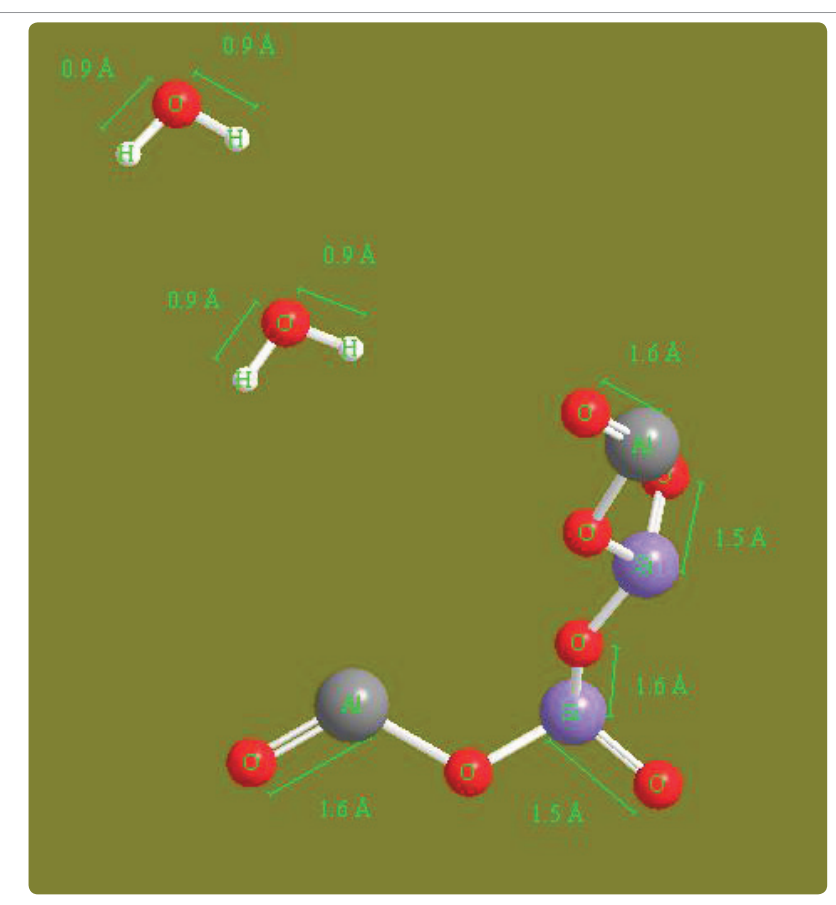

Scheme 1: Bond lengths of kaolinite.

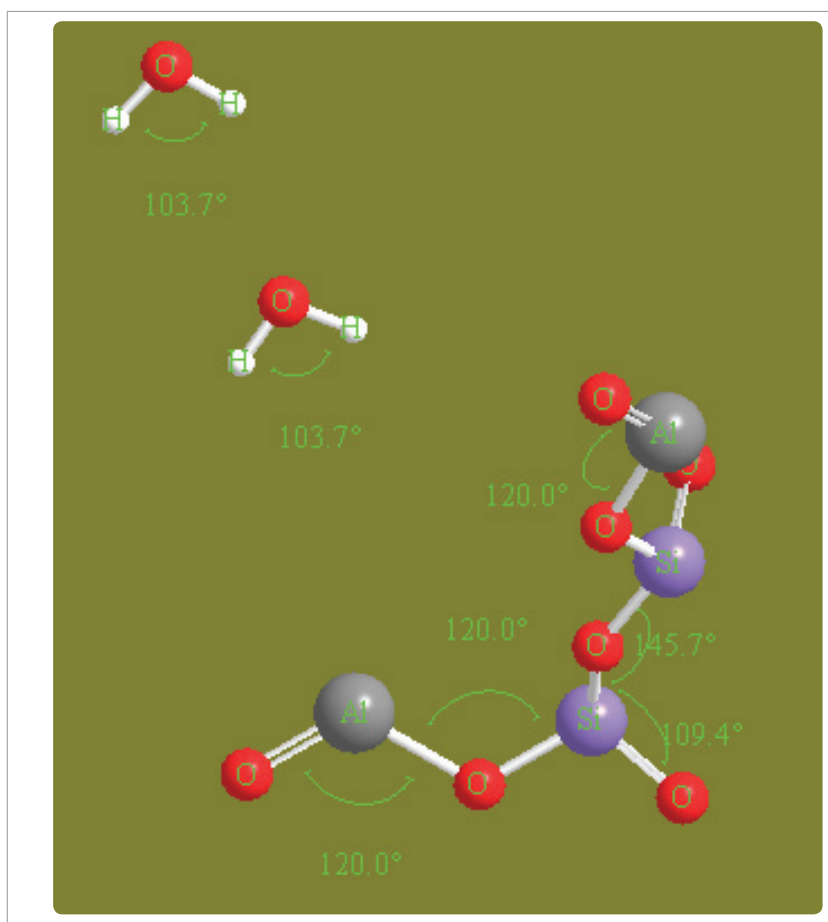

Scheme 2: Bond angles of kaolinite.

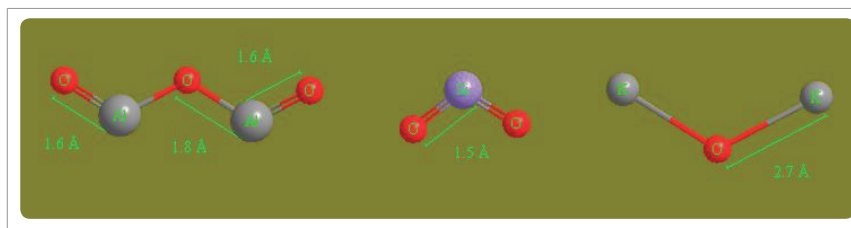

Scheme 3: Bond lengths of muscovite.

\section{MSDLPublications}

Research is creating new knowledge

Che and Ana I and Bio Chem 
Citation: Aluvihara S (2020) Assay of the Molecular Compositions of Different Clay Types based on Industrial Applications. Rea Int J of Che and Ana I and Bio Chem. 1(1): 001-004. DOI: 10.37179/rijcabc.000001.

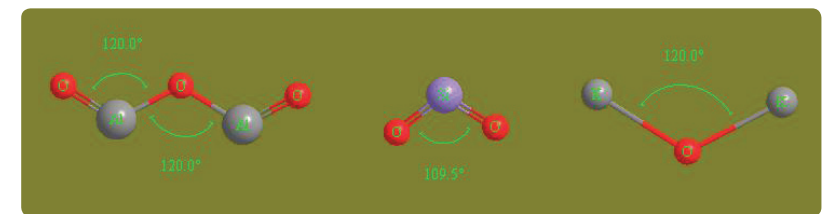

Scheme 4: Bond angles of muscovite.

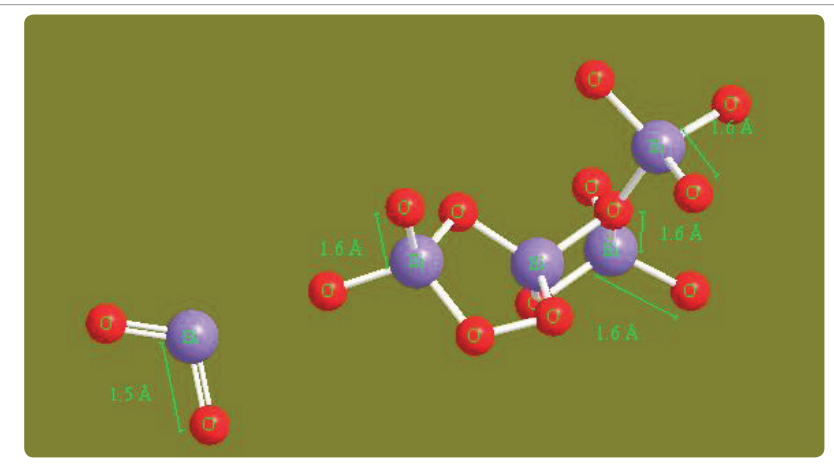

Scheme 5: Bond lengths of quartz.

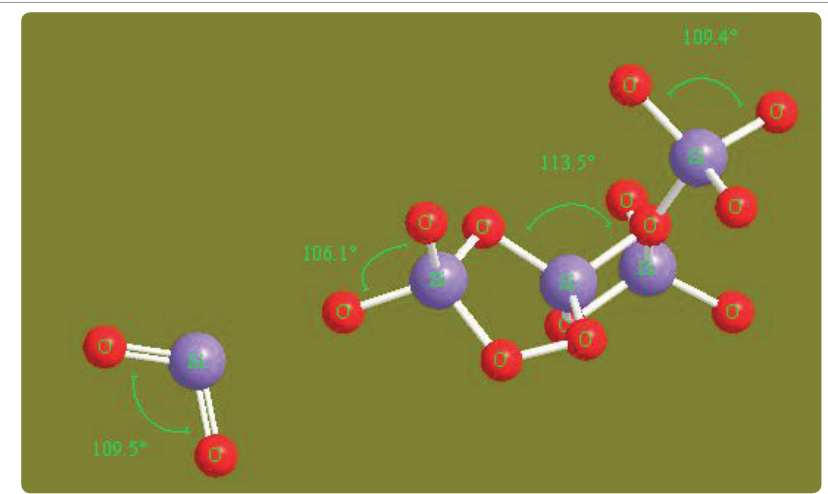

Scheme 6: Bond lengths of quartz.

\section{Conclusions}

According to the FT-IR analysis of clays, there were observed the presence of kaolinite, muscovite and quartz in each of analyzed clay type. In the clarifications of the properties of such minerals, those minerals have been identified as strong adsorbers for some other metals such as the heavy metals and pathogens.

Therefore, it is possible to conclude and suggest that the applicability of such clays for the advanced water treatment applications including the heavy metal removal and removal of some pathogens from different waste water types. Also the investigation of the chemical composition using some advanced analytical method such as the neutron activation analysis (NAA) is recommended as a future work for vast analysis of such clay including most of components.

\section{Acknowledgment}

We return thanks to the voluntary material providers and laboratory staff of department of chemistry, University of Peradeniya, Sri Lanka.

\section{References}

1. Davarcioglu B (2010) Investigation of Central Anatolian region Nigde Dikilitas (Turkey) clays by FTIR spectroscopy. Építőanyag 62: 55-60. Link: https://bit. ly/38G1UyJ

2. Maina EW, Wanyika HJ, Gacanja AN (2015) Instrumental Characterization of Montmorillonite Clay by FT-IR and XRD from J.K.U.A.T Farm, in the Republic of Kenya, Chemistry and Materials Research 7: 43-49. Link: https://bit.ly/2BS6NZE

3. Chen Y, Zou C, Mastalerz M, Suyun H, Gasaway C, et al. (2015) Applications of Micro-Fourier Transform Infrared Spectroscopy (FTIR) in the Geologica Sciences-A Review, Int J Mol Sci 16: 30223-30250. Link: https://bit. ly/31VMh53

4. Adamu MB (2010) Fourier Transform Infrared Spectroscopic Determination of Shale Minerals in Reservoir Rocks, Nigerian Journal of Basic and Applied Science 18: 6-18. Link: https://bit.ly/3218UVM

5. Swann GEA, Patwardhan SV (2011) Application of Fourier Transform Infrared Spectroscopy (FTIR) for assessing biogenic silica sample purity in geochemical analyses and palaeoenvironmental research, Climate of the Past 7: 65-74. Link: https://bit.ly/2ZdeqTb

6. Parker TW (1969) A Classification of Kaolinite by Infrared Spectroscopy, Clay Minerals 8: 135-141. Link: https://bit.ly/3gG33ZR

7. De Oliveira CIR, Rocha MCG, Da Silva ALN, Bertolino LC (2016) Characterization of bentonite clays from Cubati, Paraíba Northeast of Brazil 62: 272-277. Link: https://bit.ly/3iJX7ky

8. Abdel- Ghafar HM, Abdel-Aal EA, El Anadouli BE (2019) Iron Removal from Ground Water Using Egyptian Cost-Effective Clay Minerals, Applied Chemical Engineering 2: 1-9. Link: https://bit.ly/208SNNE

9. Nnaji CC, Afangideh BC, Ezeh C (2016) Performance evaluation of clay-sawdust composite filter for point of use water treatment, Nigerian Journal of Technology (NIJOTECH) 35: 949-956. Link: https://bit.ly/2ZUXYX1

10. Srinivasan R (2011) Advances in Application of Natural Clay and Its Composites in Removal of Biological, Organic, and Inorganic Contaminants from Drinking Water, Advances in Materials Science and Engineering 2011: 1-17. Link: https:// bit.ly/2ZUy8SL

11. Mahandrimanana A, Joseph R (2013) Physico-Chemical Analysis for Different Types of Clays Soils in the Areas of Analamanga, Itasy and Vakinankaratra, International Journal of Materials and Chemistry 3: 99-105. Link: https://bit. ly/32191k2

12. Saat A, Hamzah Z, Abu Bakar Z (2009) XRF determination of major elemental contents of clay samples from north-west peninsular Malaysia, Journal of Nuclear and Related Technologies 6: 230-236. Link: https://bit.ly/3iMoxWQ

13. Baranowski R, Rybak A, Baranowska I (2002) Speciation Analysis of Elements in Soil Samples by XRF, Polish Journal of Environmental Studies 11: 473-482. Link: https://bit.ly/2ZcbTJ7

14. Tiago RT, Cristina NL, Eduardo EAN, De Eduardo A, Maldaner LF, et al. (2019) Simplifying Sample Preparation for Soil Fertility Analysis by X-ray Fluorescence Spectrometry, Sensors 19: 5066. Link: https://bit.ly/2Ze3vsk 